\title{
Alloglugea bufonis nov. gen., nov. sp. (Microsporea: Glugeidae), a microsporidian of Bufo marinus tadpoles and metamorphosing toads (Amphibia: Anura) from Amazonian Brazil
}

\author{
I. Paperna ${ }^{1}$, R. Lainson ${ }^{2}$ \\ ${ }^{1}$ Department of Animal Sciences, Faculty of Agriculture of the Hebrew University of Jerusalem, \\ Rehovot 76-100, Israel \\ ${ }^{2}$ Seçao de Parasitologia, Instituto Evandro Chagas, Caixa Postal 691, 66017-970 Belém, Pará, Brazil
}

\begin{abstract}
A microsporidian infection, due to Alloglugea bufonis nov. gen., nov. sp., is described in the tadpoles and newly metamorphosed toads of Bufo marinus from a lake near Belém, Pará, north Brazil. Xenomas occur either singly in the lamina propria of the intestine, or aggregated into cystic bodies of up to $0.2 \mathrm{~mm}$ diameter, which emerge above the intestine surface. The xenoma is bounded by a folded plasmalemma with pinocytotic depressions, and there is a central, enlarged nucleus. Plasmodial stages and elongate meronts differentiate into ribbon-shaped sporonts and single-nucleated sporoblasts. The spore cytoplasm is invaginated at the posterior end. Spores escape from the mature xenomas into reticuloendothelial cells of the liver, spleen and kidneys of the tadpoles and newly metamorphosed toads, but infection is gradually lost after metamorphosis.
\end{abstract}

KEY WORDS: Alloglugea bufonis nov. gen., nov. sp. · Microsporidian - Xenoma development · Ultrastructure Bufo marinus Brazil

\section{INTRODUCTION}

Examination of tadpoles of Bufo marinus (the 'giant' or 'cane' toad) from the forest-fringed Lake Bolonha, on the outskirts of Belém, Pará, North Brazil, showed them to be infected by a microsporidian. This toad is the most widespread and common neotropical amphibian, and has been introduced, intentionally, to regions outside its natural range. Most notorious of these has been Australia, where B. marinus is now considered a pest (Zug \& Zug 1979).

There are many papers on the parasites of both native and introduced Bufo marinus (Delvinquier \& Freeland 1988, Speare 1990), but the only available data on microsporidia in this toad are on their occurrence as hyperparasites of Balantidium and a trematode (Delvinquier \& Freeland 1988). We describe here a previously unrecorded genus and species of a microsporidian from $B$. marinus, and its course of infection in tadpoles and post-metamorphosis toads.

\section{MATERIALS AND METHODS}

Air-dried smears prepared from toad and tadpole tissues were fixed either in absolute methyl alcohol for $3 \mathrm{~min}$ or in aqueous Bouin's fluid for $20 \mathrm{~min}$, followed by rinsing for $24 \mathrm{~h}$ or longer until colourless. The methyl-alcohol-fixed smears were stained for $1 \mathrm{~h}$ in Giemsa $(30$ drops of stain to $15.0 \mathrm{ml}$ distilled water buffered to $\mathrm{pH}$ 7.4). Those fixed in Bouin's fluid were stained in similarly diluted Giemsa for 1 h $30 \mathrm{~min}$, dehydrated and differentiated in a series of 95:5, 70:30, 30:70\% acetone:xylol mixtures, cleared in pure xylol and mounted in 'Permount'.

Tissues for histology were fixed in $10.0 \%$ neutral, buffered formalin and embedded in glycol methacrylate ('GMA', Agar Company, UK). Sections were cut at 3.0 to $4.0 \mu \mathrm{m}$ with a glass knife, on a Sorval JB4 microtome, stained with Meyer's haemalum and counterstained either with eosin or phloxin and eosin. 


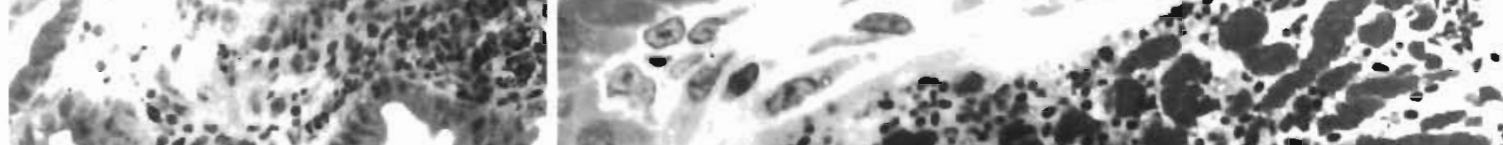

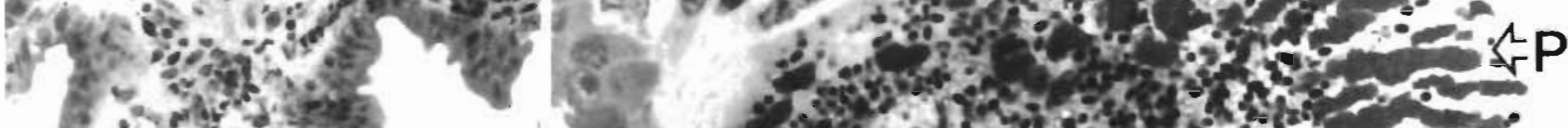

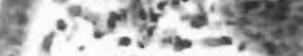

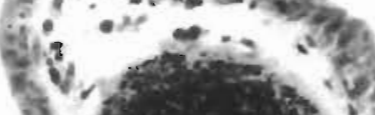

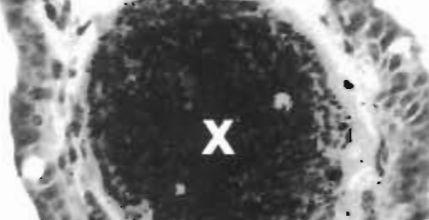

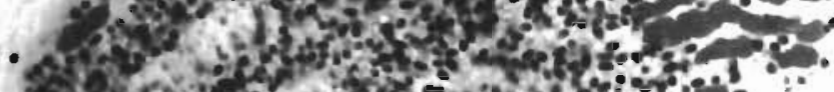

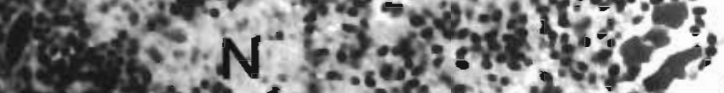

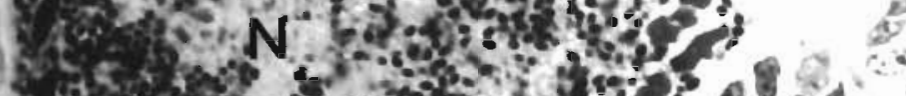

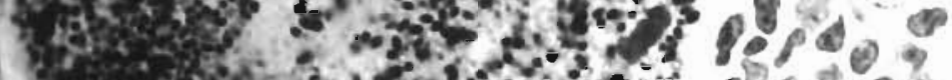

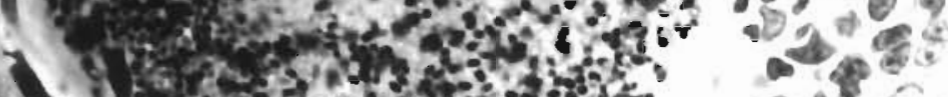

$x^{2}+\frac{3}{2}$
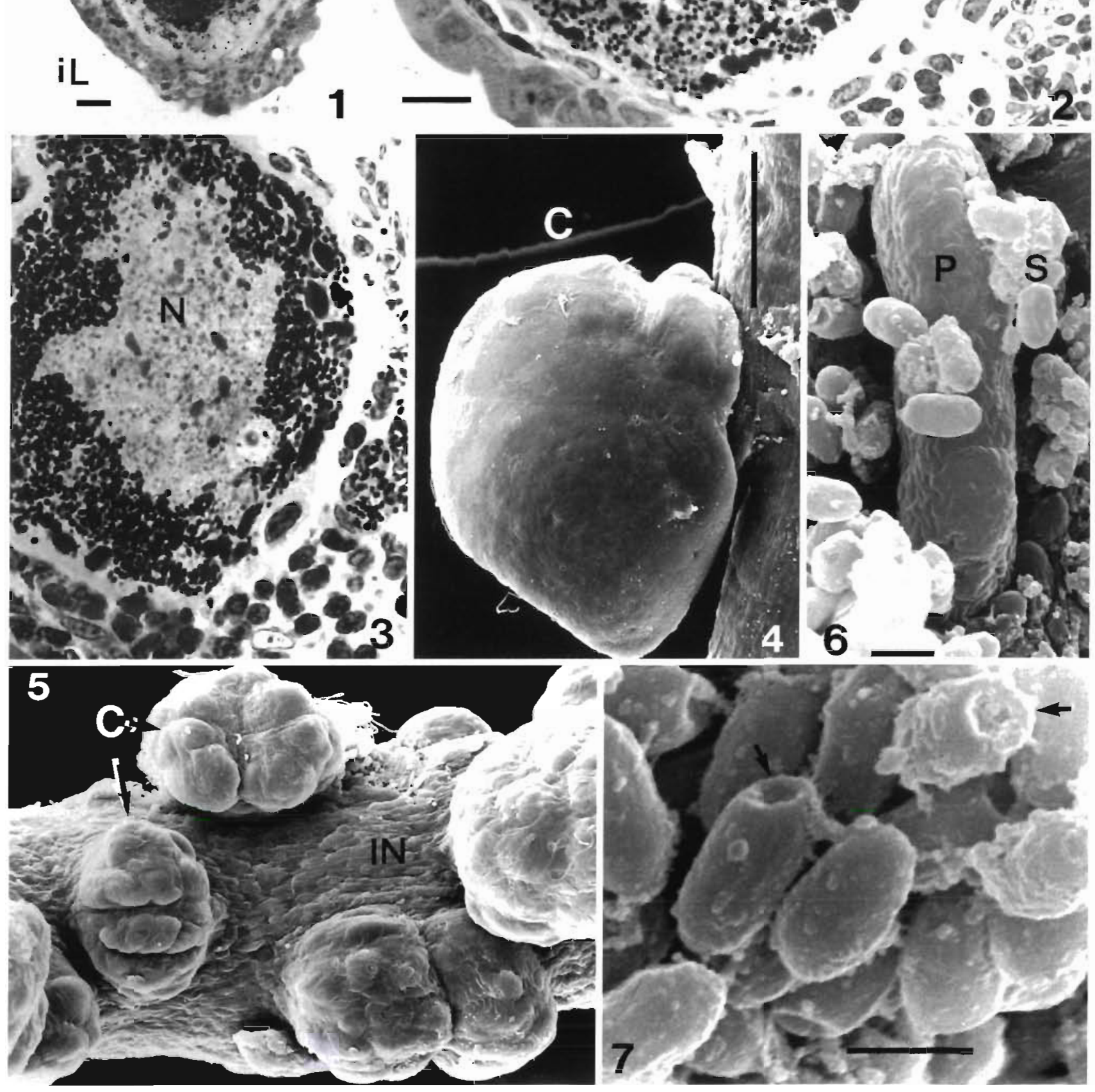
For scanning electron microscopy (SEM), intestines with the cystic bodies were fixed and preserved in neutral, buffered formalin (10.0\%). After rinsing in distilled water and dehydrating in ascending concentrations of alcohol, the tissues were critical-point dried with liquid carbon dioxide in a 'Polaron E-3000' critical-point drying apparatus and sputter-coated with gold in a 'Polaron E5100' sputter-coater. Specimens were examined and photographed using a Joel JSM 35C SEM.

Material for transmission electron microscopy (TEM) was fixed in $2.5 \%$ cacodylate $(0.1 \mathrm{~min}, \mathrm{pH} 7.4)$ buffered glutaraldehyde for $24 \mathrm{~h}$ at $4.0^{\circ} \mathrm{C}$, rinsed repeatedly and post-fixed in $1.0 \%$ osmium tetroxide, in the same buffer, for $1 \mathrm{~h}$. After further rinsing in the same buffer, the material was dehydrated in graded alcohols and embedded in Agar 812 medium (Agar Company). Thin sections, cut on a Reichert 'Ultracut' ultratome with a diamond knife, were stained on grids with uranyl acetate and lead citrate, and examined with a Joel 100CX TEM.

\section{RESULTS}

\section{Light microscopy and scanning electron microscopy of xenomas}

The microsporidian xenomas were formed in the lamina propria of the intestine, and single ones, of less than $10 \mu \mathrm{m}$ in diameter, were entirely embedded within the gut wall (Figs, 1 to 3 ). Others, of variable size, were aggregated into compound cystic bodies of up to $250 \times 200 \mu \mathrm{m}$ in size, and emerged above the gut surface (Figs. 4 \& 5).

The cytoplasm of the xenoma was denser than that of the surrounding host-cell cytoplasmic components, and was bordered by an incomplete, single layer of fibroblasts (Fig. 2). The plasmodial stages and spores were concentrated on the periphery of the xenoma (Fig. 4), around a central hypertrophic or degenerate host-cell nucleus (see also the TEM results below).

The SEM view of the contents of the cystic bodies revealed elongate and longitudinally folded plasmodial stages (meronts or sporonts) reaching $10.0 \mu \mathrm{m}$ in length (Fig. 6) and smoothly surfaced spores measuring $1.3-1.6 \times 0.6-0.8 \mu \mathrm{m}$. Some of the spores showed a sub-apical depression (Fig. 7).
Smears of ruptured cysts, stained in Giemsa and examined by light microscopy, revealed the presence of plasmodial developmental stages with a variable number of nuclei (from 13 to 80 ) and of variable size $(10.0-70.0 \times 2.0-5.0 \mu \mathrm{m})$. Those measuring up to $56.0 \times$ $7.0 \mu \mathrm{m}$, and with a lightly stained cytoplasm containing large, diffuse nuclei of about $2.0 \times 1.0 \mu \mathrm{m}$, were considered to represent the earliest stages of the meronts (Figs. 8 to $10 \& 24$ a). Others, measuring $10.0-17.0 \times$ 3.0-5.0 $\mu \mathrm{m}$, possessed a very intensely staining cytoplasm and were regarded as being later stages of meronts. Some of these contained a small number of large, dense nuclei of about $1.0 \mu \mathrm{m}$ in diameter (Figs. 11 to $17 \& 24 \mathrm{~b}$ ), while others had a larger number of smaller nuclei of about $0.5 \mu \mathrm{m}$ in diameter (Figs. $13 \& 24 \mathrm{c}$ ). Thin, ribbon-like plasmodia of 25.0$30.0 \times 1.5-2.0 \mu \mathrm{m}$, and with a single or double row of nuclei, seemed to develop following the disintegration of the stouter plasmodia (Figs. 18 to $20,24 \mathrm{e}$ to $\mathrm{h}$ ). This process is interpreted as being the transformation of meronts into sporonts. The sporonts of these winding chains broke up (Figs. 20 to $23 \& 24 i$, j) while dividing into 2 sporoblasts, apparently by binary fission (Figs, 22 \& 24i)

\section{Transmission electron microscopy of the xenoma}

The xenoma was shown to contain vertebrate-type mitochondria, endoplasmic reticulum (ER), cisternae, microfibrilar components and ribosomes (Figs. 25, 26 \& 28 to 31 ). The nucleus of the host cell was sometimes hypertrophic and bounded by a distinct nuclear membrane (Fig. 25), and on other occasions fragmented (Fig. 26). The xenomas were bordered by a fine membrane, perforated by openings leading to pinocytotic vesicles (Fig. 27),

The plasmodia have a thick wall of $50 \mathrm{~nm}$, with a heavy deposit of a granular, osmiophilic substance. Transects of these bodies revealed from 2 to 9 separate nuclei (Figs. 28 to 32 ) and showed them to vary in the ribosomal density of their cytoplasm. Those of low (Figs. 28 \& 30) and medium (Fig. 29) density contained a variable number of small ring-like organelles (possibly transects of microtubules), and thin-walled vesicles or multimembranous structures which are possibly a Golgi complex (Figs. 28 to 30). In the plasmodia with

Figs. 1 to 7. Alloglugea bufonis. nov. gen., nov. sp., from the toad, Bufo marinus. Fig. 1. Histological section of a xenoma (X) in the intestinal wall of a tadpole. iL: intestinal lumen. Figs. 2 \& 3. Enlarged view of xenomas beneath the intestinal mucosa of tadpoles, showing the hypertrophic host-cell nucleus (N), peripheral plasmodial stages $(\mathrm{P})$ and spores. Semi-thin sections from Agar 812 embedded material, stained with toluidine blue. Scale bars $=10 \mu \mathrm{m}$, and that in Fig. 2 also applies to Fig. 3. Figs. 4 \& 5 . Xenomas forming cystic masses (C) on the surface of a tadpole's intestine (IN). SEM; scale bar $=100 \mu \mathrm{m}$. Figs. 6 \& 7. Plasmodium (P) and spores (S): note the apical depression (arrowed) of a spore in Fig. 7. SEM; scale bars $=1.0 \mu \mathrm{m}$ 


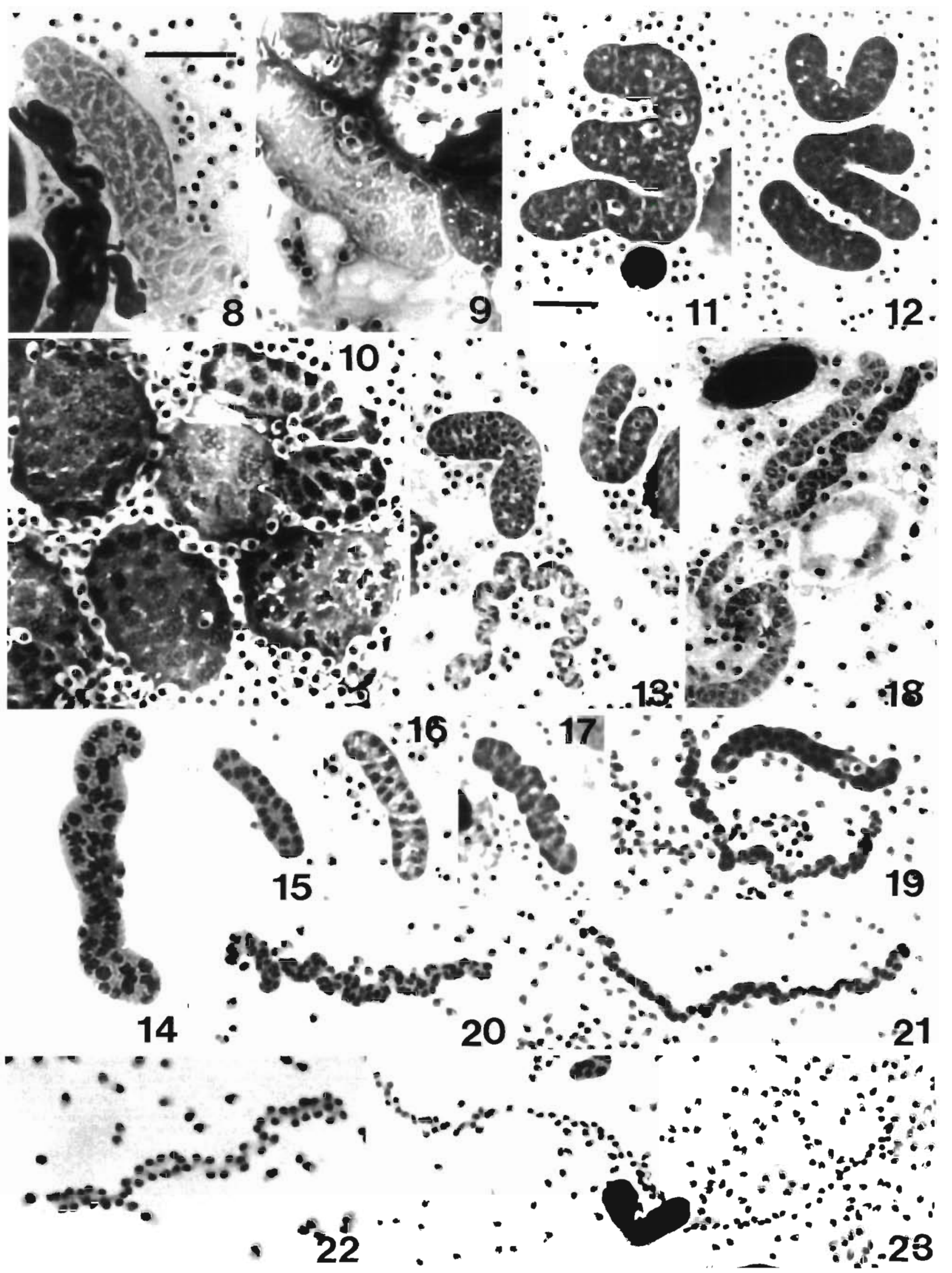


Figs. 8 to 23. Alloglugea bufonis. Giemsa-stained smears of xenoma contents, showing developmental stages from meronts to sporoblasts. Figs 8 to 10. Early meronts. Figs. 11 to 17. Differentiating meronts. Figs. 18 to 20. Transformation from meronts into sporonts. Figs. 21 to 23. Separation of sporonts into sporoblasts and spores. Scale bar in Fig. $8=10.0 \mu \mathrm{m}$ also applies to Figs. 9 \& 10. Bar in Fig. $11=10.0 \mu \mathrm{m}$ also applies to Figs. 12 to 23

the higher ribosomal density the ER was organized into a concentric pattern, while the microtubule-like structures disappeared (Figs. 30 to 32 )

Sporoblasts and spores with more than a single nucleus were not found (Figs. 33 \& 34). The spores were seen to be enclosed by a wall about $50.0 \mathrm{~nm}$ thick which appeared to have a laminated consistency of medium to low electron density, and to be coated with a light deposit (Figs. 33 to 35). In some spores an electron-dense deposit was also seen in the space between the spore wall and the cytoplasmic plasmalemma (Figs. $33 \& 35$ ). The sub-apical depression seen by SEM was also evident in TEM-viewed transects, in which it could be seen to adjoin a polar cap (Figs. 33 \& 34). The basal portion of the filament could be seen in a few tangential transects, and a vesicular polaroplast was seen in some spores. The spore nucleus was sur-

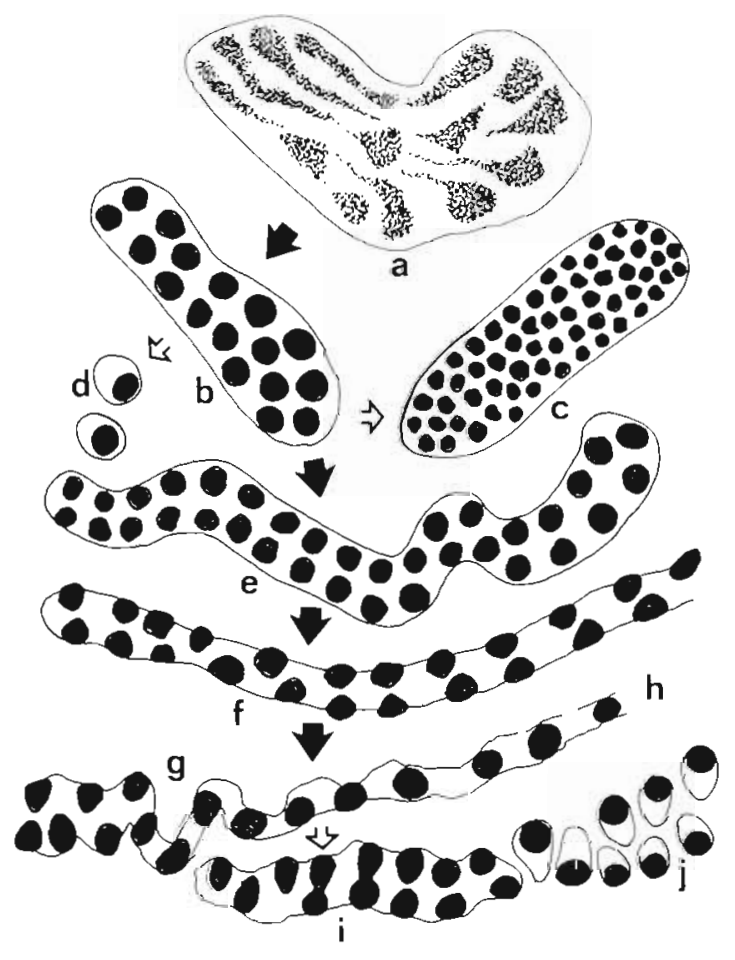

Fig. 24. Alloglugea bufonis. Diagrammatic summary of development from meronts to sporulating stages. (a) Early meronts; (b) meronts transforming into stages containing small nuclei (as in c), dissociating into single-nucleated units (as in d), or growing into long ribbon-like sporonts $(e \text { to } h)_{i}(i, j)$ sporulation into sporoblasts rounded by a flocculent sporoplasm (Fig. 35), while the cytoplasm in which the polar filament coils were embedded was densely filled with ribosomes. The polar filament appeared to form 5 or 6 coils, with whorled membranes occurring near the terminal portion (Figs. 33 \& 34). There was an invagination of the spore cytoplasm at the posterior end (Figs. $33 \& 40$ ).

\section{Tissue spores}

Spores accumulate in the macrophages (Figs. 38 \& 39) and other reticuloendothelial-type cells. They were found in both these cells and the glomeruli of the kidney (Fig. 37), in the spleen, and in the vicinity of blood vessels in the liver. TEM observations showed these spores to be of the same type as those seen in the xenomas and the phagocytes (Figs. 33 to 36). Phagocytes contained both mature, intact spores and degenerated ones, either directly embedded in the cytoplasm or lying within a vacuole (Fig. 36).

\section{Course of infection in Bufo marinus}

Infection was found in 2 consecutive generations of tadpoles, collected on 11 October and 8 November 1992 from Lake Bolonha. Infection was absent, however, in those collected from an ephemeral ditch located some distance beyond the periphery of the swampy region fringing the lake. Infected specimens showed variable numbers of large, white cysts, mostly on the surface of the intestine, and an equally variable amount of spores concentrated in the viscera. Heaviest deposits of these were in the spleen and the kidneys, resulting in the formation of white nodules in both organs. Heavy infection produced hypertrophy of the spleen, but not of the kidneys

Overall prevalence of infection in tadpoles as well as in newly metamorphosed toads ranged in the different collections from 70 to $100 \%$. Large cysts were numerous only in 1 sample of newly metamorphosed toads, up to 50 with a mean of 29 per toad. Otherwise in both tadpoles and toads the number did not exceed 5. The abundance of both cysts and spore aggregates in the viscera declined somewhat in tadpoles maintained in the laboratory for a further 44 to $47 \mathrm{~d}$, and it was noted that both infected and uninfected tadpoles failed to 


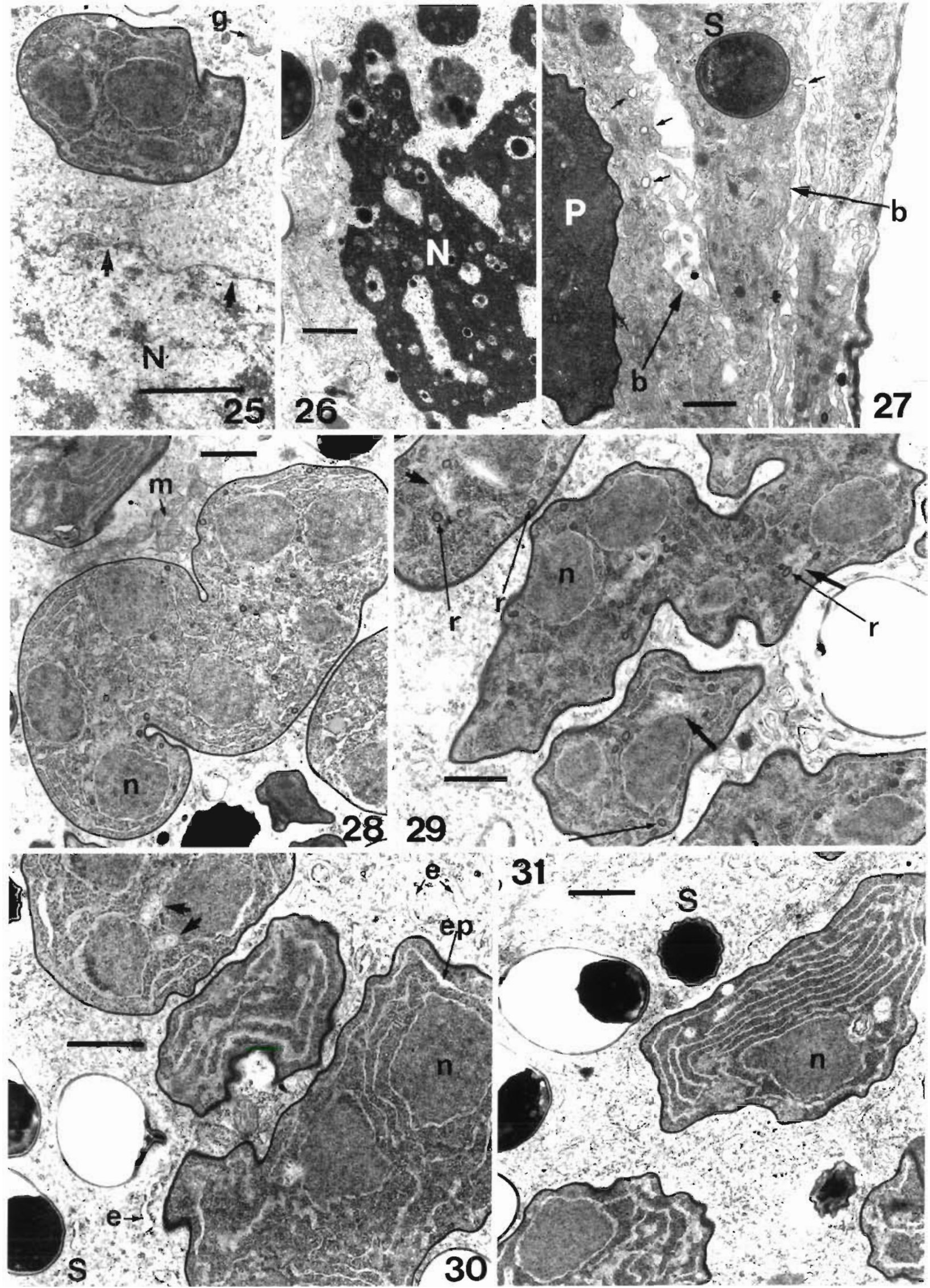


Table 1. Bufo marinus. Summary of infection incldence with Alloglugea bufonis in tadpoles and metamorphosed toads from Lake Bolonha and its surrounding area in Belém, Brazil

\begin{tabular}{|c|c|c|c|c|c|}
\hline Source & $\begin{array}{l}\text { Stage of } \\
\text { development }\end{array}$ & $\begin{array}{l}\text { Time } \\
\text { examined }\end{array}$ & $\begin{array}{c}\text { No. } \\
\text { examined }\end{array}$ & $\begin{array}{l}\text { No. with } \\
\text { cysts }\end{array}$ & $\begin{array}{c}\text { No. with } \\
\text { visceral spores }\end{array}$ \\
\hline Ephemeral pools & Tadpoles & $\begin{array}{l}\text { Day } 0 \\
\text { In lab Day } 28\end{array}$ & $\begin{array}{r}20 \\
4\end{array}$ & $\begin{array}{l}0 \\
0\end{array}$ & $\begin{array}{l}0 \\
0\end{array}$ \\
\hline Lake Bolonha & Tadpoles & $\begin{array}{l}\text { Collected } 11 \text { Oct } \\
\text { Collected } 6 \text { Nov } \\
\text { In lab Day } 24 \\
\text { In lab Day } 43 / 47\end{array}$ & $\begin{array}{r}6 \\
22 \\
7 \\
12\end{array}$ & $\begin{array}{r}6 \\
16 \\
4 \\
5\end{array}$ & $\begin{array}{l}2 \\
5 \\
7 \\
7\end{array}$ \\
\hline & $\begin{array}{l}\text { Toads (post metamorphosis) } \\
8-10 \mathrm{~mm} \text { long } \\
11-12 \mathrm{~mm} \text { long } \\
12 \mathrm{~mm} \text { long } \\
13-16 \mathrm{~mm} \text { long } \\
19-25 \mathrm{~mm} \text { long } \\
26+\mathrm{mm} \text { long }\end{array}$ & $\begin{array}{l}\text { Collected } 6 \text { Nov } \\
\text { In lab Day } 5 \\
\text { In lab Day } 28 \\
\text { In lab Day } 43 / 47 \\
\text { In lab Day } 50\end{array}$ & $\begin{array}{r}5 \\
12 \\
11 \\
14 \\
5 \\
8\end{array}$ & $\begin{array}{l}5 \\
9 \\
7 \\
3 \\
0 \\
1\end{array}$ & $\begin{array}{r}2 \\
12 \\
9 \\
6 \\
1 \\
1\end{array}$ \\
\hline Wild caught & Adult toads & & 19 & 0 & 0 \\
\hline
\end{tabular}

metamorphose under these conditions. The cysts, and subsequently also the tissue spores, gradually disappeared in growing toads of 13 to $26 \mathrm{~mm}$ in length, both in captive individuals and those newly captured from the margin of the lake. No infection was found in 7 older toads, measuring from 26 to $40 \mathrm{~mm}$ captured on the lake shore, or in 19 fully grown specimens collected from the same locality. Scanty spores were detected, however, in a smear of kidney tissue from 1 adult toad obtained on a different date from another locality. Data on the tadpole and toad infections are summarized in Table 1.

\section{DISCUSSION}

The presently described microsporidian from Bufo marinus cannot readily be placed in any previously recorded genera of the Microsporea and we propose, therefore, to give the organism a new generic and specific name within the family Glugeidae Thelohan 1892 , as defined by Lom \& Dyková (1992).

Definition: Alloglugea bufonis nov. gen., nov. sp. (Figs. 1 to 40). An apansporoblastic microsporidian of the family Glugeidae, forming a xenoma, with the hostcell nucleus retained in a hypertrophic or fragmented condition. Meronts elongated, with numerous separate nuclei and differentiating into ribbon-like, multinucleate sporonts. Sporonts dividing directly into sporoblasts which become detached and develop into uninucleate, thick-walled spores. Surface of the spore above the polar cap often depressed, and there is an invagination of the spore cytoplasm at the posterior end. After release from the xenomas, spores accumulate and persist for some time in the host reticulo-endothelial and mesenchymal cells. At present, the genus is represented by only 1 species, Alloglugea bufonis n. sp.

Type host: Bufo marinus (Amphibia: Anura: Bufonidae), the 'giant' or 'cane' toad.

Type locality: Lake Bolonha, Belém, Pará, north Brazil.

Type material: Holotype and syntype smears and histological sections deposited in the Department of Animal Sciences, Faculty of Agriculture, Hebrew University of Jerusalem, Rehovot 76-100, Israel.

Etymology: the generic name is from the Greek allos, other, and glugea from the genus Glugea; namely, 'not Glugea'. The specific name is derived from the generic name of the host in which the parasite is described, Bufo marinus.

The only undoubted microsporidian previously reported from amphibians is Plistophora myotrophica.

Figs. 25 to 31. Alloglugea bufonis. Transmission electron photomicrographs of xenomas. Scale bars $=1 \mu \mathrm{m}$. Fig. 25 . Border zone of the hypertrophic host-cell nucleus $(\mathrm{N})$. Nuclear membrane indicated by bold arrows; g: host-cytoplasm Golgi complex. Fig. 26. Fragmenting, hypertrophic host-cell nucleus of a xenoma. Fig. 27. Border of a xenoma (b), showing openings to pinocytotic vesicles (small arrows); P: plasmodium; S: spore. Fig. 28. Low density plasmodium, with ring-like organelles (see Fig. 29, r); n: one of the plasmodial nuclei; m: xenoma mitochondria. Fig. 29. Medium density plasmodium with ring-like organelles (r) and multimembranous vesicles (bold arrow, and see also in Fig. 30). Figs. 30 \& 31. Dense plasmodia, with concentric endoplasmic reticulum 


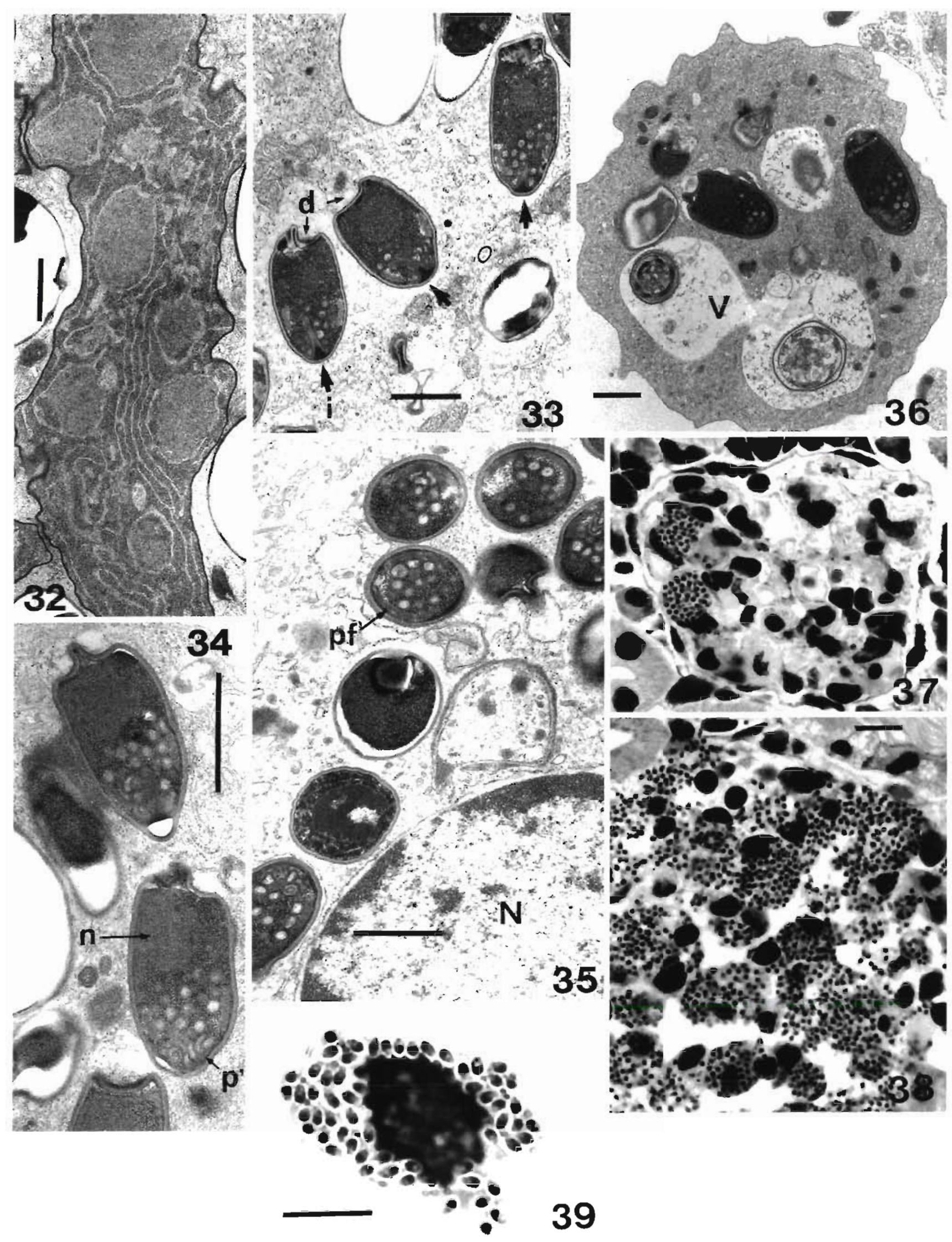


Figs. 32 to 36. Alloglugea bufonis. Xenomas and spore ultrastructure. Scale bars $=1 \mu \mathrm{m}$. Fig. 32 . Section of dense plasmodium, showing approximately 10 nuclei. Figs. $33 \& 34$. Free spores within the xenoma. d: apical depression adjoining the apical cap; $i$ and bold arrows: posterior invagination of the spore cytoplasm; $\mathrm{p}^{\prime}$ : whorls connected to the polar filament; $\mathrm{n}$ : plasmodial nucleus. Fig. 35. Spores in a somatic cell, outside the xenoma. N: host cell nucleus; pf: polar filaments. Fig. 36. Intravacuolar (V) and intracytoplasmic spores in a leucocyte-like cell

Figs. 37 to 39. Alloglugea bufonis. Spores in tadpole's tissues; light microscopy of haematoxylin/eosin stained sections. Scale bars $=10 \mu \mathrm{m}$. Fig. 37. Accumulated spores in the kidney glomerulus of a metamorphosing toad. Fig. 38. Spores in reticuloendothelial cells of the kidney, from the same toad. Fig 39. Macrophage, packed with spores

infecting the European toad Bufo bufo (Canning \& Elkan 1964). Glugea danilewskyi, found in both frogs and turtles of the Ukraine in 1891 by Danilewsky, remains of doubtful validity (Reichenbach-Klinke \& Elkan 1965).

Alloglugea somewhat resembles Glugea species infecting fish in that it induces xenomas, has elongated plasmodial stages, sporonts which divide directly into 2 sporoblasts, and uninucleated spores. Glugea, however, is pansporoblastic, and its development from meronts into sporoblasts and spores is different from that of the presently described parasite: its meronts round-up to form uninucleated sporoblast mother-cells by multiple fission, and these further divide into 2 sporoblasts (Lom \& Dyková 1992).

Resemblance to the recently described Nosemoides tilapiae by Sakiti \& Bouix (1987), also from fish, is limited to the production of uninucleate spores.

There is a superficial resemblance to Encephalitozoon (see Canning \& Lom 1986), but the accumulation of the spores of Alloglugea in macrophage-like cells is simply by phagocytosis, following their release from the xenomas in the host gut-wall. Phagocytosis of spores following collapse of the host cell, or the xenoma, does occur in other microsporidian infections, but the engulfed spores seem to lose their infectivity and are ultimately destroyed (Lom \& Dyková 1992). In tadpoles and young toads infected with $A$. bufonis, the massive accumulation of spores in the different organs seems to be an integral part of this microsporidian's life history and the spores remain intact, and seemingly infective, for some time.

Ultrastructurally, a noteworthy finding is the presence of the pinocytotic vesicles, which open at the surface of the xenoma. Similar vesicles in the superficial strata of the xenomas of Glugea anomala have also been noted (Lom \& Dyková 1992). The extreme folding of the xenoma surface of Alloglugea bufonis is found in other groups of microsporidians (Desser \& Batra 1989), as is the smooth spore surface and the sub-apical depression (Lom \& Weiser 1972): the posterior invagination of the spore cytoplasm, however, seems to be unique. Finally, microtubules have not previously been mentioned in descriptions of the meronts of microsporidians, and none of the previously described plas- modial stages of the microsporidia of vertebrates possess the highly ribosome-dense cytoplasm, with such precise concentric formation of endoplasmic reticulum, as is seen in some of the plasmodial stages of the presently described parasite.

Infection with Alloglugea bufonis has, so far, only been found in Bufo marinus: it is largely confined to tadpoles, but persists throughout the process of metamorphosis. In spite of seemingly severe pathology induced by the accumulations of spores in the spleen and kidneys, even heavily infected tadpoles succeed in metamorphosing.

Tadpoles appear to become infected by consuming spores released from dead companions, or by eating their tissues. Cannibalism was often observed among Bufo marinus tadpoles when held in aquaria, and may be a further option for transmission. The occurrence of transmission in large, permanent bodies of water, and its absence in transitory aquatic habitats, suggests that spores cannot survive desiccation.

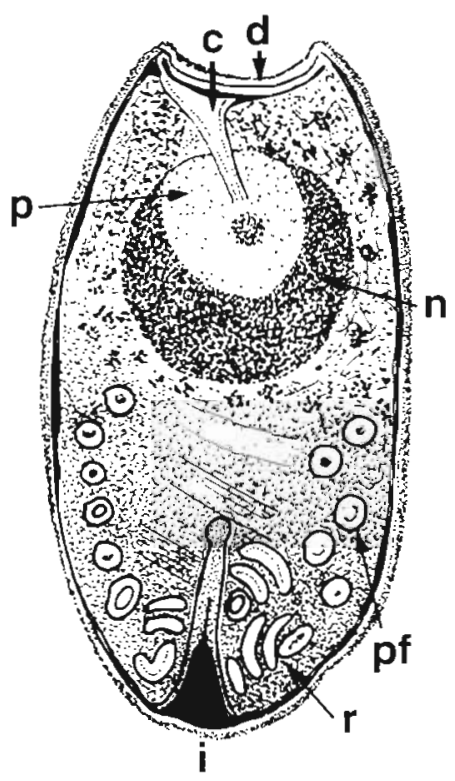

Fig. 40. Alloglugea bufonis. nov. gen., nov. sp. Line drawing to show spore structure. c: polar cap; d: sub-apical depression; $\mathrm{i}$ invagination; $\mathrm{n}$ : nucleus; $\mathrm{p}$ : polaroblast; pf: polar tube; $\mathrm{r}$ : whorls of the polar filament 
Acknowledgements. The authors thank Soo Hyun Kim for processing the specimens for electron microscopy, Marina Schein for the preparation of the histological material, Constância M. Franco and Manoel C. de Souza for technical help in the field and the laboratory. Supported by grant 035693 from the Wellcome Trust, London (R.L.).

\section{LITERATURE CITED}

Canning EU, Elkan E (1964) Plistophora myotrophica spec. nov., causing high mortalities in the common toad Bufo bufo L., with notes on the maintenance of Bufo and Xenopus in the laboratory. J Protozool 11:157-166

Canning EU, Lom J (1986) The microsporidia of vertebrates. Academic Press, London

Delvinquier BLJ, Freeland WJ (1988) Protozoan parasites of the cane toad, Bufo marinus in Australia. Aust J Zool 36: $301-316$

Responsible Subject Editor: P. Zwart, Utrecht, The Netherlands
Desser SS, Batra JR (1989) Nosema jirivavrai n. sp. (Microsporea; Protozoa) from the leech Batrachobdella picta in Ontario. Can J Zool 67:2640-2645

Lom J, Dyková I (1992) Protozoan parasites of fishes. Elsevier, Amsterdam

Lom J, Weiser J (1972) Surface pattern of some microsporidian spores as seen in the scanning electron microscope Folia Parasitol (Prague) 19:359-363

Reichenbach-Klinke $H_{1}$ Elkan E (1965) The principal diseases of lower vertebrates. Academic Press, London

Sakiti NG, Bouix G (1987) Nosematoides tilapiae n. sp. Microsporidie parasite de poisson Cichlidae des eaux saumâtres du Benin: implantation et caractères ultrastructuraux. Parasitol Res 73:203-212

Speare R (1990) A review of the diseases of the cane toad, Bufo marinus, with comments on biological control. Aust Wildl Res 17:387-4:10

Zug GR, Zug PB (1979) The marine toad Bufo marinus: a natural history resume of native populations. Smithsonian Contrib Zool 24:1-58

Manuscript first received: February 7, 1995

Revised version accepted: April 7, 1995 